\title{
Organising Rural Women for Socio-Economic Development and Self-Reliance in Nigeria: Challenges and Prospects
}

\author{
Christiana Kayinwaye Omorede ${ }^{1}$ \\ ${ }^{1}$ University of Benin, Benin-City, Nigeria \\ Correspondence: Christiana Kayinwaye Omorede, University of Benin, Benin-City, Nigeria. E-mail: \\ ckomorede@yahoo.com \\ Received: March 14, 2014 \\ Accepted: May 17, 2014 \\ Online Published: May 21, 2014 \\ doi:10.5430/bmr.v3n2p47 \\ URL: http://dx.doi.org/10.5430/bmr.v3n2p47
}

\begin{abstract}
This paper focused on organising Rural Women for Socio-economic Development. It was set out to assess the role and impact of organisations and NGOs on rural women in Nigeria with particular reference to Edo-State. It also did a critical examination of the problems inherent in rural women's participation in development.

Primary and Secondary data were used to carry out the set objectives. The paper examined and adopted the participatory development framework in its analysis. The research identified various income generating activities of rural women to include; agricultural produce, marketing of farm produce, crafts making and food processing. It was found that despite all the efforts women put in development, women's capacities are not optimally utilised due to socio-cultural and political hindrances, such as access to land, loans, education and other outputs. Other hindrances are gender issues which lead to marginalisation and non-inclusion of women in the nation's top decision-making positions. The paper concluded that organising women is an integral aspect of socio-economic advancement of any nation. It was stressed that women's efforts would optimally be utilised for socio-economic development which will consequently lead to self-reliance, if they are empowered socially, culturally, politically and economically. It was recommended among other things; that government and government agencies should integrate more women into top policy making positions for their optimum capabilities to be utilised.
\end{abstract}

Keywords: Socio-Economic, Self-Reliance, Development, Nigeria, Africa

\section{Introduction}

\subsection{Background of the study}

Organising rural women for socio-economic development and self-reliance is a major thrust in planning process aimed at enhancing women's participation in developmental activities. African women, particularly rural women primary contributions to their households, food production systems and in universal economies cannot be overemphasised. Their contributions in development are progressively being more recognised within the country and the entire world. Forum that recognised the dilemma of third world's women and of course Nigerian Women are the 1995 Nairobi Forward Looking Strategies for Advancement of Women held in Kenya, the 1995 Beijing Declaration, the 2000 Millennium Declaration of the United Nations Development Fund for Women (UNDFM), the Food and Agricultural Organisation (FAO) and gender and Development Plan of action 2000-7, among others. These bodies have articulated laws that offer enabling milieu for women integration into national economy mainstream. These bodies have all approved the full plan of action to advance the conditions and rights of women in their communities to promote women's socio-economic reliance. These plan of action include; creation of employment, access to resources and credit, eradication of poverty and hunger, combating malnutrition/ poor health and illiteracy of women as well as to ensure the inclusion of women in all efforts at ensuring sustainable development (Chen et al; 2005).

Karl (1995) stressed that the goals of development cannot be attained without women's full participation in development process and also in shaping its goals. Women themselves have improved their own recognition over the years through their vigorous and conscious efforts in organising and articulating their concerns and in making their voices heard through prominent groups such as Women Non-Governmental Organisations (WNGOs) with the hope of empowering themselves. The WNGOs have women and the girl-child as the main target with the aim of emancipating the female gender, attempting to improve their standards of living and fighting against gender inequality (Akpabio; 2007). 
International Agencies and National Government laws provide opportunities for women's inclusion into nations economy mainstream coupled with women's own efforts for self-reliance; nonetheless, these are yet to translate into significant development goals for rural women. Also the enthusiasm exhibited by women in economic, cultural and social lives of their communities through organisations and informal networks has not been channeled into creative models of participation and leadership.

Development is not an isolated activity. It involves progress from a lower state to a higher and preferred one. It is also a process by which people are motivated to exploit opportunities within their reach (Olopodenia; 1983 and Pradip; 1984). Development therefore starts with people and progresses through their activities (Seer; 1981 and Gwanye; 1989). Majority of the population in the Less Developed Countries (LDCs), live in rural areas with approximately 70 per cent being women (Kongolo and Bamgose; 2002). In Africa, rural women contribute almost $80 \%$ of food production consumed in most rural areas, yet they are maginalised in terms of their needs to progress and are not often featured in socio-economic development initiatives (Kongolo and Bamgose;2002).

\subsection{Statement of Problem}

In Nigeria women are generally the most neglected and they have consistently lost out in the course of development and in self-reliance. This situation is worse for the rural women. Based on this situation the Lagos Plan of Action for economic Development of Africa in line with the UN charter advocates the needs, rights and concerns of all women to be fully incorporated into individual's country's development planning to benefit all sector of the population. This does not seem to be feasible in the rural areas of Nigeria. This is why focusing on rural women for development is apt in this study. Rural women not only care for the families, they are responsible for marketing the excess farm produce from their husbands farm and are also involved in other petty trades which enhance the economic base of the family yet they are often times not included in development activities. The problem of this paper is thus situated on the ineptness of government and the society on organising rural women to achieve socio-economic development and self-reliance.

\subsection{Research Questions}

The following questions are asked to direct the course of this study.

- What is socio-economic development?

- What effects do women organisations have in the development of rural women?

- What are the hindrances to rural women participation in development?

- How do we curb these bottle necks?

From the above questions raised the aim of this paper includes the following:

- To examine the concept of development.

- To assess the impact of women organisations on rural women.

- To ascertain the bottlenecks or challenges to rural women participation in development

- To recommend solutions that enhances women's participation in their self reliance/ development.

\subsection{Methodology}

In the course of this work, primary and secondary sources were used. The researcher interviewed some Women Organisations / NGOs in Egor market, Ovia North- East local Government social welfare department officials, and some farmers. Secondary sources included materials from books, journals, and articles from Universities and libraries. The internet was also a very useful access in the collection of secondary data. The paper employs the analytical framework in its discussion.

\subsection{Limitation of the study}

The scope of the paper is limited to Edo state of Nigeria. The reason is that Edo State is a major state in Nigeria.

\subsection{Organisation of the Paper.}

The paper is organised as follows: Section 1 contains the introductory section above. It is followed by section 2 which presents the conceptualisation of (Development) the major term used in the research. The rest of the paper is organised into six sections as follows; section 3, the literature review which presents the traditional roles of women and the theoretical framework which is situated within the participatory development framework. These are followed by 4 which present findings, analyses and discussions of the role of women organisations on rural women socio-economic development. 5 explain the challenges in organising rural women for socio-economic development and self-reliance. 
In section 6 the prospects in resolving the problems in organising rural women for socio-economic development was discussed. Finally, the conclusions and recommendations are found in sections 7 and 8 respectively.

\section{The Concept of Development}

There is no single acceptable definition of the term development. In simply terms development refers to the benefits from economic growth. Development is associated with the decrease or eradication of poverty, inequity and joblessness in the context of an emergent economy. Development could further be said to involve a deep transformation of the entire economic and social structure of a community, increases production, accomplishment and enhances growth which may consequently promote economic development particularly if it improves infrastructures (Onokerhoraye; 1995, Jacobs, Garry and Asokan; 1999, Riggs; 1970). In other words development includes other important and related attributes notably; equal opportunities, political freedom and civil liberties. The overall goal of development is to increase the economic, political, social and civil rights of all people across gender, ethnic groups, religion, races and countries. Hence, Ojo (2003) summated development as the welfare and quality of life of the populace.

Development is a multidimensional process involving the re-orientation of the whole economic and social systems. It not only includes improvements in incomes and outputs, it naturally involves extensive changes in institutional, social and administrative structures as well as in accepted attitudes, mores and beliefs of the people (Todora; 1992). It is also acknowledged that at the level of individuals, development implies increased skills and capability, greater freedom, creativity, self-discipline, responsibility and comfort (Rodney; 1986). The achievement of any of the above attribute of personal development is greatly associated with the state of the society as a whole. In like manner Obasanjo and Mabogunje (1991) explained that development is a process that deals with a people's capacity in a defined area over a defined period to manage and induce positive changes. Nwachukwu (2006) outlined Mustafa's meaning and concept of development to include among others the following;

- Self-reliant development within natural resources constraints

- $\quad$ Cost effective development using different economic criteria to the traditional approach that is to say development should not degrade environmental quality, nor should it reduce productivity in the long run.

- Health control, appropriate technologies, food, self-reliance, clean water and shelter for all and

- People centeredness or human beings being the resources in the concept of development.

Corroborating the above argument the Human Development Report (2005) asserts that human development is about freedom and building of human capacity. This includes the range of things that people can do and what they can be. In other words the individual freedom and rights are central to development. This is because people are restricted in what they can do with their freedom if they are poor, ill and illiterate, discriminated against, threatened by violent conflict or denied a political voice. Hence United Nations (UN) advocates a "larger freedom" which is human development. This is why progress towards the Millennium Development Goals (MGDs) offers a proof for progress in human development. MGDs also posits that the most essential potentials for human development include; leading a long and healthy life, being educated and possessing adequate resources for a decent standard of living and having access to social and political participation.

From the above discussion development is only relevant to the extent that it brings about positive transformation that enhances the well-being of citizens as human beings are the primary beneficiary of development.

\subsection{Literature Review}

Women represent majority of the world's population (United Nations Report: 1989). The situation is not different in Nigeria. This is evidenced in Eweama (2009)report that in Nigeria women make up about half of the nation's population taking into account the 1999 census of 50 per cent and the 2006 census of 49 per cent respectively. Despite their numerical strength Nigerian women like their counterparts in other African Nations have received only a small share of the opportunities and benefits of development. Traditionally the Nigerian woman is synonymous with the "home and Kitchen." She is generally considered incapable of handling challenging responsibilities. Carlix and Eagle (cited in Imogie; 2009) argue that it is generally alleged that women are not as competent as their male counterparts to hold leadership positions. However, in recent times women advocates have challenged the stereotypes depicting women as passive dependents and even inferior to men (Hamra; 2008). Moreover these traditional beliefs are generally fading away as women are beginning to measure up with greater responsibilities like their men folks.

That women constitute an important resource in development cannot be overemphasised. It has been acknowledged that no country can aspire to achieve its full development and industrial potentials unless all of its human resources 
both male and female are mobilised to participate fully in development process (Karl; 1995, Obansa; 2003 and Obasanjo; 2006). For democracy to make meaningful impact in Nigeria there must be an appreciable number of women in the top decision-making positions. In recognition of the above argument the National Economic Empowerment and Development Strategies (NEEDS) seeks to fully integrate women in development by enhancing women's capabilities to participate in economic, social, political and cultural life of the country; through perceived measures like; ensuring equitable representation of women in the country in all aspects of national life, by using affirmative action to ensure that women represent at least 30 per cent of the work force and implement the provision of the UN convention on elimination of all forms of discrimination against women, include women's concerns and angle in all policies and programmes, promote access to microfinance and other poverty alleviation strategies with a view to reduce poverty among women (National Planning Commission 2005).

In Nigeria, Women particularly the rural women perform all forms of domestic tasks. Women are responsible for the care of children, the ailing, and the aged. As home makers they are not left out in contributing substantially to the nation's economy as food producers, processors and sellers. In Africa three quarter of the agricultural work is done by women while in Asia, Latin America and the middle East, women comprise half of the agricultural labour force (Prakash;2003). Also in a survey of nine African countries in 1996 it was found that women's contribution to the production of food crops range from 30 per cent in Sudan to 80 per cent in the Republic of Congo. (Munah; 2008).Similarly in Edo State of Nigeria, rural women constitute the bulk of the labour force. They contribute much of the labour for men's cultivation of cash crops particularly as the male working population migrates to the urban centres in search of better job opportunity and satisfaction. This puts women as a vital resource in the rural areas. Daramola (1987) observed that women account for 60 per cent in rural employment of the total share of non-farm economic activities, which implies a substantial proportion of both management and self employment in non-farm enterprises. Several other studies also have indicated that women make significant contributions to socio-economic development especially towards agricultural, health projects and establishment of skill vocational centres (Oguono; 2006, Adekanye; 1998, Makinwa- Adebuseye; 1985, Enumali; 1995, Longe; 1985, Tewe; 1978, FAO; 1985, Lele; 1975, Oshuntogun; 1976, Patel; and Anthonio; 1973 and Smock and Smock; 1972).

It has been established that many rural women are members of "women only mutual-aid societies," such as church benevolent organisations, co-operatives and market women's organisations. Some of these women's only aid societies allow women to pool their resources together with the aim of assisting the needy among them (ESCAP; 2012, Munah; 2008, Eshiet;2007, Emovon; 1997, ECA;1990 and Dunmade; 1990). Munah (2008) also captured the experience of some African countries which shows that some cooperative societies have provided women access to resources, such as the Corn Mill Societies in Cameroun, the Six S' associations in Burkina Faso and General Union Cooperatives in Mozambique which supplies most Maputo's fruits and vegetables. Also an estimated 90 per cent participate in traditional women's savings and credit associations. Informal rotational credit in Ghana, Tanzania, Gambia, and Zimbabwe have been used by estimated 25 per cent of economically active women in the non-agricultural informal sector to invest in Businesses and farms; home improvement and costs of schooling for their Children.

\subsection{Theoretical Framework}

According to Rostow (1960) the economic modernisation theory based on the superiority and desirability of western style modernisation and growth presume that all countries will grow from a traditional to modern society, following the same path of development similar to those of already experienced by the "advanced western nations". For third world nations however, some scholars such as McClelland (1961) Hagen (1962) and Lewis (1966), argued that the contrary is the case as third world nations are riddled with numerous constraints and structural bottlenecks such as traditionalism, low savings, high population and low achievements. Thus, infusion into foreign aid, investment and technological assistance deemed necessary for growth and expects that this growth will trickle down to all strata of the economy was constrained. In practice development as growth paradigm resulted in the paradox of apparent growing wealth and greater poverty. This inadequacy of the growth paradigm to tackle third world underdevelopment led to a search for alternative strategy (Eshiet; 2006).

Eshiet (2006) further argued that the 70s witnessed a shift in the conceptualisation of development from capital centeredness to people's centeredness, because capital centeredness had hitherto either bypassed or marginalised people in its concern to build and construct physical structures. Though Physical development is important, it is argued by some proponents that it must be approached in a manner that would enable people to have a central role and control over it.

Many other scholars such as Galjart (1981), Bhasin (1985), Fulglesang and Chandler (1986) and Oakley (1991) have all supported the above view and have constantly used development, as "participatory development" or people 
centered development in their analyses. Their analyses emphasised the need to adapt the basic approach of development to the social, political and economic context of the people. The major thrust in their argument is; (a) that poverty is structural and has its root in the economic and political conditions which influence rural people's livelihoods, (b) that development programmes and projects have largely by-passed the vast majority of rural people hence there is need to have a rethink on forms of developments interventions to ensure that the neglected majority has a chance to benefit from development initiatives.

The Overseas development Administration (ODA;1995) defines participatory development as a process by which people take active and influential part in shaping decisions that affect their lives. As a process, it carries the people along throughout the development cycle. Through it, all those who have an interest play active roles in decision-making and in all activities that affect them. 'Participatory development', the reverse of the traditional "top-Down" method of development does everything possible to involve the people in policy formation, adoption, implementation, monitoring and evaluation that will ultimately affect their lives (Oakley;1991).

Oakley (1991) identifies two distinct aspects of this approach; they are "Participation as a means" and "participation as an end". In his estimation Participation is a means when it is used to achieve predetermined goals, in this case participation is the means through which accessible communal resources of rural people is used to attain developmental programmes and projects. He concludes that "Participation as a means focuses on results of participation rather than on the act which is the achievement of the targets". This makes participation passive and short termed in nature, as participation terminates at the completion of a particular task. Conversely, participation as an end is essentially a process which unfolds overtime and whose purpose is to develop and strengthen the capabilities of rural people to intervene more directly in development initiatives. Such a process may have or may not have predetermined measurable objectives. As an end participation is active and dynamic because it enables rural people to play an increasing role in development activities (UN; 1995). This approach is supported by the African Charter for Popular Participation in Development (ACPPD) According to (Adedeji; 1990) ACPPD believes that "popular participation provides the driving force for collective commitment for the determination of people-based development process and willingness of the people to undertake sacrifices and expand their social energies for its execution." Participation as an end empowers the people and it is the fundamental right of the people to fully and effectively participate in determining the decision that affects their lives. Adedeji also argues that people's participation is the engine for launching the process of economic transformation while UNDP (1998) asserts that people's participation is the motor for accelerating the process of change and development. The Arusha Charter therefore urges people to establish community based autonomous organisations as a plat-form for articulating their interests (UN; 1989). Popular participation empowers women to be self-reliant when they are genuinely involved in participatory programmes that will lead to decision-making processes at the conceptualisation, formulation and implementation stage of development project that is meant for them. This inversely leads to consensus building between them and government. It also empowers women to improve on their socio-economic status quo and dismantle institutions, structures, beliefs and attitudes etc which seek to degrade womanhood and deny her equity as a person. Consequently our analysis for this paper is situated within the participatory development framework.

\section{Findings, Analysis and Discussions on the Role/Impact of Women Organisations on Rural Women Socio-Economic Development}

Table 1. Activity, Number and Local government areas of operation of NGOS in Edo State

\begin{tabular}{|c|c|c|c|c|c|}
\hline \multirow[t]{2}{*}{$\mathbf{S} / \mathbf{N}$} & \multirow[t]{2}{*}{ Nature/area of activities } & \multirow[t]{2}{*}{$\begin{array}{l}\text { No. of } \\
\text { NGOs }\end{array}$} & \multirow[t]{2}{*}{$\begin{array}{l}\text { LGA of } \\
\text { Operation }\end{array}$} & \multicolumn{2}{|c|}{$\begin{array}{l}\text { Year } \\
\text { registration }\end{array}$} \\
\hline & & & & $1-5$ yaers & $\begin{array}{l}6-10 \\
\text { years }\end{array}$ \\
\hline 1 & Health & 30 & 8 & 23 & 7 \\
\hline 2. & Education & 16 & 6 & 14 & 2 \\
\hline 3. & Socio-Economic empowerment & 36 & 7 & 29 & 7 \\
\hline 4 & Governance/development & 14 & 5 & 12 & 2 \\
\hline 5 & Community Development & 10 & 5 & 9 & 1 \\
\hline 6 & Human- Rights & 19 & 6 & 17 & 2 \\
\hline 7 & Philanthropy & 15 & 2 & 14 & 1 \\
\hline 8 & Enlightenment & 25 & 7 & 21 & 4 \\
\hline 9 & Environment & 2 & 2 & 2 & - \\
\hline
\end{tabular}

Source: Edo State Official Website 2009 http://www, edostate.gov.ng/ngo.php. 
Table 1 above indicates the activities of the NGOs in Edo State. It also indicates the number of NGOs and their local government areas of operation in the state.

From the table thirty (37\%) NGOs are geared towards Health projects, and they operate within eight (8) local government areas. In respect of educational projects, sixteen NGO's (19.8\%) operate in six local government areas. The NGOs geared towards enlightenment and Human-Rights programmes are twenty- five or $30.9 \%$ and nineteen or $23.5 \%$ respectively.

Associations /NGOs in the area of governance are fourteen or $17.3 \%$ in only four local government areas of the state. In respect of NGOs contributions to women's Socio-Economic Empowerment are thirty-six i.e. 44.4\% NGOs are involved in this area and they operate in seven local government areas of the state. Other areas of activities of the NGOs include; community Development, Environment and Philanthropy, with a few local areas of operation.

The study revealed that non Governmental Organisations (NGOs) play a dual role in socio-economic development and self-reliance of the rural women in Edo State. Through their participation in these organisations many rural women are empowered to access loans from micro finance bodies and so may become more economically and socially enhanced. It was found that rural women maintain cohesion among themselves through different social-economic activities/ NGO's they engage in. Such activities involve attending marriage ceremonies, funeral ceremonies and other social engagements of members. While economic activities are directed towards trading, carrying out of some skilled occupations, weaving, cooking, food processing, smoking of fish, poultry, hair dressing, animal husbandry, snail rearing etc. Women become economically empowered as they decide the use of proceeds from these economic activities to carry out functions that demonstrate financial independence. They also develop the capacity to take decisions such as sending their children to learn, trade or to go to school.

Over the years different women organisations have emerged with improved quality in their works. They have taken advantage of new political opportunities to raise issues that concern them in new ways and they have even had to form alliances with other civil society groups to advance women rights. Some of the groups have received external funding while others seek and stress on internal responsibility. Nigerian women and gender issues affecting women are now discussed most often within the framework of rights. Sub-regional affiliations of women have also been formed to resolve the problems of women participation in rural development activities.

The study revealed that the Mrs. Mariam Babangida's "Better Life Programme (BLP) for rural Women designed to improve the quality of lives of women through its cooperatives, agricultural production, cottage industries, skill acquisition and health care helped to raise the level of productivity as well as generate more income and employment for women. The programme more importantly tried to integrate the rural women into the mainstream of nation's building. It also attempted to change the behavior of the rural women who had hitherto been marginalised, hidden and ignored despite their implicit contributions to the socio-economic development of the country. On the other hand "The Edo State Women Association (ESWA), in affiliation with the African Families Foundation (TAFF), launched a fund drive and was able to get the French Embassy to fund the building of a modern day-care centre in Santana market. The day-care centre is also used as a community resource centre which offers training courses and apprenticeship schemes for young people in home-keeping, childcare, computer, hair dressing, carpentry and other employment teaching skills. ESWA also has a micro Loan scheme for women. The scheme is categorised into \#100,000, \#50,000 and \#25,000 respectively. Sixty-seven (67) women from three women groups access the loan on a rotational bases, while interests raised is used to run the costs of the daycare centre (ESWA;2010). It is noteworthy that in spite of limited fund available to ESWA and these organisations they have managed to make meaningful contributions to development in the lives of women and the communities at large. Women who otherwise would have remained dependent on their husbands and others have themselves become participants in development activities and are self reliant through the activities of ESWA. Other activities of ESWA include Africa Dance and Aerobics Classes (a non medical intervention for the management of cardio-vascular Health problems). Groups such as "Sustainable Environment Initiatives" Asebe Shehu Yar-Adua Foundation", Noble Family Foundation", are all geared towards bringing changes in socio-economic participation and the rights of women in Edo state.

"The Mothers of Niger-Delta" Edo State is geared towards organising on the issues of peace, unity and stability of the Niger Delta Mothers. Their challenges include; resources and legal recognition to rebuild their lives and to participate in peace-building, conflicts resolution and early warning mechanisms (Edo State website 2010). "The Edo State Women Association" is directed towards assisting market women with facilities for the advancement of education of their children. They enhance their health and general living standards. These Organisations are both watch dogs and catalysts to the continuous developmental processes of rural communities as they carry out several income generating activities to improve their lots. The "Caring Women in Ministry" in Oredo local Government has programmes aimed at 
reaching out to the needy through skill acquisition in tailoring. The Igarra Torch Bearer" on its part organises programmes for grass root women of Igarra to sensitise them on economic empowerment that will enhance productivity in their chosen trade. Other Organisations like the "Great Women Multipurpose Co-operative Society" of Oredo, Willi Johnson Foundation" of Owan-West and Centre for Women and "Child Development" respectively are all directed towards socio-economic empowerment of the rural women. Sometimes, women who belong to these groups are brought together on the initiative of international NGOs to learn basic skills to improve on the health of their babies/children, or to learn better ways to use indigenous baby health food or even to learn how to improve on their farming methods and their health status. Such women group extends their participatory activities to include literacy, family planning, weaving etc.; this eventually improves their knowledge not only on home management but also on their communication capability, which in turn enhances their simple decision-making habits. "The Weppa Wanna Women in Action" of Etsako-East, encourages Adult Education as they educate women on family, health and general good governance. Same is applicable to the "Society for Women and Aids in Nigeria Edo State Chapter". These groups help to sensitise, educate and raise awareness of women and youths especially the poorly educated women in relation to the AIDS epidemic and related problems. In Egor area of the state, personal interactions/ interviews with some market women and Local government social Welfare department revealed that the Awuewengbe Market Women group of Uselu market and Evboutubu Market Women respectively, have benefited from the technological advancement in food processing such as cassava processors. On the other hand the Iyanga Market Women group has enhanced their self-reliance through modern fish smoking technology provided by the Market Organisations/ NGOs. This has also reduced the man-hour through more efficient processing methods and has brought about improvement in rural women's income. Equally the "Action for Community Development" of Egor, embarks on family planning, education, development projects income generation for women and provides free computer training for youths as well as organises programmes on enlightenment on HIV/AIDS reproductive health among others. These Women Organisations discussed above are making a push for efficient changes in women's lives.

From discussion of findings above, it is evident that cooperatives have become a sustainable organisational framework for accelerated rural development and are useful instruments for the mobilisation and sensitisation of women in the state, hence cooperative formation has largely been embraced by women of the state because of its importance in increasing their credit worthiness and placing them in a position of strength to support income generating activities from their pooled resources. Governments, Bilateral and Multilateral Agencies and other NGOs must collaborate with them for meaningful change to occur in the lives of women in particular and the society at large. Generally speaking though the activities of these NGOs are of good intentions and serve as a strong motivating force on the rural women for organisational work, their impact have not matched their expectations due to limited fund. This corroborates with Manuh (2008) and Oakley (1991). Also women's interests and needs are not properly articulated into development policies. The next section of this paper thus looks at the constraints in organising rural women for socio-economic development and self-reliance.

\section{Challenges in Organising Rural Women for Socio-Economic Development and Self-Reliance}

Women are the moral fiber of the rural economy in most Sub-Saharan Africa. 80\% of the economically lively female labour force is engaged in agriculture. Also women comprise $47 \%$ of that labour force (Eshiet; 2006). In Nigeria agriculture and food production is the major activity of the rural women. It has been stated earlier that women responsibilities and labour inputs often exceed those of men in most areas in Africa. For Nigeria to achieve a sustainable agricultural sector the involvement of rural women in popular participation and addressing the constraints they face must be considered. This we believe will make the agricultural sector the wheel of economic growth for the rural areas. Below are the constraints faced by women in rural areas of Nigeria.

\subsection{Access to Land, Finance, credit and other Inputs}

Rural women in Nigeria face a number of problems that hinder them access to land, credit facilities, machinery, extension services, agricultural training and access to good markets. This corroborates FAO (2008) on nine countries which showed that women rarely own land and when they do; their holdings tend to be smaller and less fertile than those of men. Customarily in Edo State of Nigeria, access to Community Land is directed by Community laws. Traditional pattern of inheritance bequeaths family property including land to men. This has hampered rural women access to land as well as property which could be tendered as collaterals for securing loans with financial institutions as banks usually demand collateral in the form of landed property and male approval before granting loans to women. Often times, rural women rely on highly priced money lenders to invest in some productive ventures which they eventually find difficult to repay. Manuh (2008) found that only five per cent of the resources provided through services in Africa are available to women and of total extension agents at work in Africa today only 17 per cent are 
women. Also structural adjustment policy exacerbated some of the obstacles that confront women farmers by placing greater emphasis on export crops, which usually are grown by men and the domestic terms of trade have tended to shift against food production where women are predominant as a result only a few women farmers are able to market enough of their own produce to benefit from higher producer prices. Low incomes, lack of access to good markets among others are factors pushing many rural women away from traditional agriculture.

5.2 Labour is also a constraint that militates against rural women farmers, particularly as the men working class has left rural economies in search of more viable livelihoods, leaving the women to do most of the work. In areas like; Egbean, Obazuwa and Usen in Ovia North-East, Aroko in Etsako-West and Emuhi in Esan-West, it was revealed that exodus of young men is very high. This has influenced the sexual division of labour for the few left behind.

5.3 Marginalisation of women in Edo State is another problem confronting women in their socio-economic development. The gender division of labour in the society prescribes certain roles as men's and others as women's. This is a major source of women discrimination in rural development efforts. Rural women organisations and groups contribution to socio-economic development is perceived as social and voluntary and thus has no economic values. This corroborates Eshiet (2006). The stereotyping of women as weak and helpers to men rather than individuals with economic and political roles in their own rights has created barriers to women's groups' access to opportunities for economic advancement. This corroborates Carlix and Eagle (cited in Imogie; 2009). This is further compounded by women's under representation in top positions in public and private sectors. Gender disparities are among the deepest and most pervasive of inequalities. Nowhere are power inequalities and their consequences more clearly displayed than for women in Edo-State, ranging from household to the national levels. It was widely accepted that even government seldom integrates women in the mainstream of the nation's development policies. Despite the present democratic dispensation and given the achievements and numerical strength of women in Nigeria and by implication Edo State, government still has not adequately integrated women into the mainstream of the nation's development policies. Moreover, conventional practices and approach toward women have been passed over into public life to the extent that government policies do not adequately address the peculiar needs of women in the rural development process therefore; women are under-represented in organs of government, legislative bodies, and local political structures. Hence the concern and interests of women are not taken care of both at national and state level discussions; even where they have been, they have been insignificant. This situation works against women because low participation in policy and in decision making reinforce the obstacles to social and economic inclusion. If women are not adequately represented their needs are unlikely to be heard and taken seriously. Presently in Edo State, there is only one woman out of the twenty-four seats in the state house of assembly and in the local governments, women are scarcely represented. This also applies to village councils and leadership positions. This corroborates Eshiet (2006).

Also the type of development policies in existence, tend to neglect the informal sector, where women are predominant, women need to be fashioned into the main stream of development strategies as suggested by Eshiet (2006).

Inadequate education and skills are major constraints to women progress and employments. In most cases families prefer to send boys to school, seeing little or no need for educating the girl-child who according to them will soon be married off to other families who will become the beneficiary of the education gains of the female child. Also issues such as adolescent pregnancy, early marriage and greater weight on girls and household labour act as obstacles to their schooling. Moreover, girls from a society such as ours, that is suffused with gender biases, end up in conventional "feminine jobs" in teaching, nursing and clerical jobs (even when men are also found in the above mentioned jobs, they are stereotyped "feminine" in our society). In science where they could develop better skills to secure a better employment, women are in the minority. This corroborates Imogie (2009).

Women's roles as care providers hinder their participation in income generating activities. Sometimes women have to take very young children with them to the market where they spend all day. In Edo state there is no free public pre-school provision or else it is prohibitively expensive. In addition the traditional Nigeria welfare structure based on the extended family system which allows women to keep their children with older members of the family has been seriously eroded by nuclear family structure which is alien to us.

Other problems militating against rural women in development include; the issue of reproductive health system, access to portable drinking water, energy supply, and effective transportation of their farm produce. This is exacerbated by corruption which is rife in Nigeria. For instance, market women are constantly harassed by some hoodlums who make them pay unauthorized taxes. Even the authorized taxes paid; frequently do not get to state coffers as some officers or agents in charge help themselves with such funds. This corroborates ESWA (2010). All these are some obstacles to rural women's socio-economic development and self-reliance. 


\section{Prospects in Resolving the Problems in Organising Rural Women for Socio-Economic development}

Organising rural women have great implication in enhancing socio-economic development hence the possible ways of resolving the problems that hinder rural women from popular participation in the development process should be discussed and settled to enhance development. Since rural women constitute the bulk of agricultural producers there is need for government, community and institutions to demonstrate commitment to removing socio-cultural impediments against women particularly in the rural communities where women are economically viable through their involvement in agricultural activities. The constraints on rural women access to land, credit facilities, extension services and other inputs such as new technologies must be eradicated while more opportunities should be made available for their organisations and groups. Measures to enhance women's access through institutional reforms must be pursued and monitored vigorously for effectiveness. This will enhance food production and food security at reduced rates since costs of foods are essential components of the cost of living. An improved agriculture that ensures the achievement of large increase in food supply as well as raw materials would stem the rate of inflation and imports bills are likely to fall. Similarly with increased output of agricultural exports foreign exchange would increase which in turn improves the balance of payments position of the country. This corroborates Onokerhoraye (1995). Government should necessarily be in partnership with various women organisations such as the great women Multi cooperatives Centre for Women /Child Development and Edo state Women Association ESWA with a view to creating an enabling environment for credit to be made available to rural women at affordable rates. Rural women should also be able to get access to credit/ loan, based on their own recognition. Furthermore benevolent organisations such as the international Christian Centre for Missions (Home for Needy, the Noble Family Foundation etc.), should complement Government efforts by assisting rural women with grant-in-aids.

Prescribed roles /labour for males and for females should be discouraged. The consequences for unequal division of household labour may affect the zeal for competence among the females in the society in areas termed "males jobs".

In reducing time spent for labour, appropriate technologies for food processing, preservation and storage should be made available as accomplishment to farm tools that are appropriate for women, including transportation equipment that will free women from head loading. Increased provision of portable water, cheap and reliable energy supply are also needed to reduce long hours that women work. As care providers, many economic programmes in Nigeria tend to over look the unpaid economy, where women predominate. Gender bias and rigidities may affect women's access to productive resources and markets, ultimately frustrating economic reform policies. It is therefore important to take into consideration gender bias and tailor planned interventions to improve women's ability to take advantage of incentives, thus enhancing overall economic efficiency.

Given the required financial, technical aid and incentives from government and relevant agencies, women could then be organised into small scale food processing enterprises such as fruits extraction, oil and flour processing. Other skills acquisition activities such as weaving, and pottery could be established too. New technologies to reduce waste (in terms of produce extracted manually) generate more employment opportunities which will lead to increased rural income. This will inversely reduce rural -urban migration. There is no gain saying that gender issues have been widely discussed at various conferences; such as those held in Nairobi 1985, Beijing 1995, 2000 Millennium Declaration of the United Nations Department Fund for women as well as the FAO Gender and Development plan of 2000-7. These conferences and declarations were all focused towards women gaining equality with men and being heard in the society. Wiley and Eskilson (in Imogie; 2009) have proffered solution to dissuade gender stereotyping by suggesting that "women should act more like men." Women should therefore work harder to assert themselves in their efforts to participate more actively in socio-economic development. There should be an ultimate change of attitude towards gender relationships, and men should come to the understanding that what a man can do a woman may even do better. This will engender fair power sharing between men and women, which will subsequently bring peace and stability to the society. Men should appreciate that sharing of power with women could result in peace both at home and in public work environment. This is based on the knowledge that the absence of women in decision-making situation has led to strife and war in the world and the role of women in the establishment of the United Nations when compared to the league of Nations (Alele-Williams;2008).

Policy makers should listen to women and include them in decision making as this will improve their status. An all inclusive approach must be taken by government in conjunction with development agencies and women themselves to remove socio-economic and socio-cultural constraints on women. National action plan must be designed in broad consultation with women organisations to complement rural initiatives which must be adequately funded and staffed. Often times similar institutions have been marginalised, under-resourced and used as a dumping group for gender issues (Munah; 2008). To this end, organising rural women could be used as channels for mass mobilisation as well as 
tools for dissemination of information on government development programmes such as family planning, health education, adult literacy, political participation etc. In this way women organisations help in bringing rural women closer to government and invariably results in grass-roots participation in governance with the accompanying dividends. Women's commitments to their households, to local and national food security, local production and the environment should be reflected in equitable representation on all bodies that make decisions in these areas, as well as in broader economic programmes that affect women's lives.

There is need to enlighten the general public on gender biases in the enrolment of the girl-child particularly in rural areas. Girls should be given equal opportunities for achievements. On the other hand, school curricula should incorporate concepts of gender equality and peace at all levels to enable students incorporate them into their lives. Young women should be exposed to functional education and skills to play meaningful roles in the society. Moreover, parents should encourage both sexes in their entire Endeavour's by giving them equal opportunities. Furthermore extra efforts should be put in place to motivate the girl-child /women in actualising their potential in education so that they can actively participate in socio-economic development and be self-reliance.

\section{Conclusion}

The paper was set out to investigate the problems and prospects in organising rural women for socio-economic development and self reliance in Nigeria. Based on the findings arising from the analysis of data derived from the study a number of conclusions have been reached. Firstly women organisations/cooperatives contribute significantly to socio-economic development especially in the area of agriculture, health/child care projects and establishment of skilled vocational centres. This is because these organisations pool resources together to assist the financially weak ones among them.

Furthermore the study revealed that organising rural women for socio-economic development and self-reliance is very essential in the advancement of any nation because no nation can grow above the perceived development of her women folks who form the bulk of the productive sector. In Nigeria women are socio-economic contributors to development. This not only benefits the women but all Nigerian. However finding of this research, show that women are marginalised in participating in socio-economic activities and in matters that concern them. Such that Women are not included in decision making processes, they are not given access to land property and they lack adequate education to enhance their participation in socio-economic activities.

This paper thus advocates that the society should be responsive to the needs of women by focusing more on women's activities and desires. Ignoring their needs and desires will amount to huge setback to development. Another conclusion of the study is that discrimination, inequality in opportunities, low access to land property and low access to finance limit women capabilities in development and self reliance. Addressing the unequal balance in decision-making, power and control in relation to men and women in the household, workplace, communities and at national Government level expectedly will ultimately ensure an all round empowerment process that will no doubt hasten the socio-economic development process of Nigeria.

In summation this study concludes that rural women would contribute maximally to the socio-economic developmental processes of the nation given an enabling environment devoid of discrimination against women, non-participation of women in policy-decisions in issues concerning them and poor educational background of most women among other things.

It is hoped that government agencies, at all levels including individuals would begin to redirect their attention towards adopting appropriate policies and actions that will place rural women in a position of strength for socio-economic development which eventually leads to self-reliance.

\section{Recommendations}

(1) Traditional factors threaten development in the education and training of women and the girl -child. In order to avoid gender discrimination of low enrolment of women or the girl-child training programmes are needed to develop their technical competence. This will enable them to be better informed, better gain access to the political and economic structure and help them gain maximum competence and means of livelihood.

(2) Since women represent about fifty per cent of the nation's population, there is need to have adequate representation of women in high decision making positions in government. This will also be in keeping to the Beijing Declaration recommendation of $30 \%$.

(3) There should be concerted efforts on the part of government in conjunction with the NGOs and development agencies to remove or curtail socio-economic and cultural constraints on rural women in accessing land, loans, and 
other inputs. Government must ensure that stringent measures in these facilities are minimized through special Women's Banks.

(4) National Action Plan in line with the Beijing platform for Action should be considered in broad consultation with women organisations in order to complement local initiatives. This also should be adequately financed.

(5) Women organisations in the communities and trade places should be acknowledged by governments and NGOs for meaningful change to occur in the lives of women and the society at large. These women organisations should be used as an avenue to increase women participation and decision-making in the community.

(6) Basic infrastructures and support services such as roads, electricity, good drinking water, health and day care centres as well as transportation must adequately be provided.

\section{References}

Adekanye, T. O. (1998). Women in African Agriculture", Journal of the Institute of African Studies 3, 1-5.

Adeniji, A. (1990). The African Alternative: Putting the People First, Arusha (CEA).

Alele-Williams, G. (2008). "Research Priorities for Sustainable Women Empowerment and Development: An Overview", P. Adeniji (ed.) Research on Capacity Building for Sustainable Development in Nigeria.

Akpabio, I. A. (2007). "Women NGOs and the Socio-economic status of Rural Women in Akwalbom State, Nigeria" in Journey of Agriculture and Social Science, No. 1813-2235,-1-1-6(http://www.fspublisher.org.)

Bhasin, K. (1985). Towards Empowerment Rome: Food and Agricultural Organisation of the United Nations, UN Pub.

Carlix \& Eagle (Imogie A. O. 2009). "Overcoming Huddles of Stereotypes about Sex and Leadership" in Benin Journal of Gender Studies, Benin Nigeria, Vol. 1, No. 2., p.195.

Chen, M.C., F.W. Vanek, J.Heintz, et al. (2005). Progress of the World's women work and Poverty, (New York: Unifem, pp.75-83.

Daramola, A. G. (1987). "A Quantitative Analysis of the Adoption of Improved Food Production Technology in Oyo State, Nigeria" Uni. of Ibadan, Ph.D Thesis.

Dunmade, V. B. (1990). “Approaches to Promoting Peoples Participation in the Recovery and Development Process: A Case of Nigeria, "International Conference on Popular Participation in the Recovery and Development Process in Africa, Arusha, Tanzania, $12^{\text {th }}-16^{\text {th }}$ February, p.12.

ECA. ( 1990). Manual on Typologies and Activities of Rural Organisations in Agriculture and Rural Development in selected African Countries Addis Ababa, Ethiopia pp.1-83. )

Edo State Official website. (2009). http://www.edostate gov.ng/ngo.php.

Emovon, A.C. (1997). Women of Power: A Study of Market Women's Associations in Benin-City, Bendel State of Nigeria" Queens, Queen Mothers, Priestesses, and Power. Case Studies in African Gender. (Ed.) Kaplan, F. E. S. The New York Academy of Sciences, New York. http://dx.doi.org/10.1111/j.1749-6632.1997.tb48130.x

Enumali, N.N. (1995). "Women in Agriculture: Neglect of Rural women's role in agriculture". Paper presented at the seminar on women in Development. Institute of African Studies, Uni. of Ibadan, Ibadan.

ESCAP, (2012), The Education of Women, http://www.unescap.org.

Eshiet, I. (2006). "Harnessing the Socio-Economic Potentials of Rural Nigeria: The Role of Rural Women Association", Proceeding of Fifteenth Annual Congress in Nigerian Rural Sociological association (NRSA) on Unlocking the Agricultural and Rural Development Potentials of Nigeria, Ado-Ekiti, $6^{\text {th }}-9^{\text {th }}$ Nov.

ESWA( 2010). "Edo State Women Association, Foundation Laying". www.edo.women.com.

Eweama, P. (2009), “Gender Statistics in Nigeria, Issues and Challenges”, UN Global Forum, Ghana.

FAO. (1985). Women in Agricultural Production Human Resources, Institutions and Agrarian Reform Division, Rome Food and Agriculture Organisation.

Fulglesang, A. \& D. Chandlier. (1986). Participation as a Process: What We Can Learn from Grameen Bank (Bangladesh: NORAD).

Galjart, B. (1981). "Participatory Development Projects: Some Conclusions From Research", in Rural Sociology, Vol. 21, No.2pp.142-159. http://dx.doi.org/10.1111/j.1467-9523.1981.tb01085.x

Gwanye, T. T. (1989). Rural Development Planning in Developing Countries", A Fact Paper No. 5, (Transkei: 
University of Transkei, Bureau of Development Research and Training.

Hagen, E.E. (1962). Theory of Social Change, (IIIinois: Dorsey Press).

Hamra, I. (2008). "Research Priorities for Women Empowerment and Development: Problems and Prospects" in Research Capacity Building for Sustainable Development in Nigeria, Peter Adeniyi (ed.) Lagos.

Human Development Report. (2005). "The State of Human Development", International Cooperation at a Cross roads: Aids, Trade and Security in an Unequal World, UNDP, pp.18-19.

Imogie A. O. (2009). "Overcoming Huddles of Stereotypes about Sex and Leadership" in Benin Journal of Gender Studies, Benin Nigeria, Vol. 1, No. 2., p.195.

Jacobs, Garry \& Asokan. (1999). "Towards a Comprehensive Theory of Social Development Administration" in Human Choice, World Academy of Art and Science, USA: p. 152.

Karl, M. (1995). Women Empowerment: Participation and Decision Making (London and New-Jersey: Zed Books Limited), p.173.

Kongolo, M \& O.O.Bamgose. (2002). "Participation of Rural Women in Development a case study of Isheseng, Ihintwa and Makhakneng Villages, south Africa," Journal of International women studies,-113052907, Nov.(http://www.Accessmylibrary.com/article).

Lele, U. J. (1975). The Design of Rural Development in Tropical Africa. Hongkong: Longman.

Lewis,W.A. (1966). Development Planning: The Essentials of Economic Policy, London, Allen, Urwin.

Longe, O.G. (1985). The role of women in food Production: processing and Preservation. Paper presented at the seminar on Women in development. Institute of African Studies, Uni. of Ibadan, Ibadan.

Makinwa-Adebuseye, P.K. (1985). "The Socio-economic contribution of Nigrerian Women to national development". Paper presented at the seminar on Women in national development. Instituteof African Studies, Uni. of Ibadan, Ibadan.

Manuh, T. (2008). "Women in Africa's Development, Overcoming Obstacles, Pushing Progress", in Africa Recovery, UN pub.

McClelland. (1961). The Achieving Society, New-York: Free Press.

National Planning Commission. (2005). National Economic Empowerment Strategies, (Abuja, Central Bank, pp. 44.

Nwachukwu, L.C. (2006). "Promoting Sustainable Development in Nigeria through Participation", International Journal of Science and Policy Issues, Nigeria, ISSN Vol. 4. Nos. 1 and 2, p.103.

Oakley, P. (1991). Project with People: The Practice of Participation in Rural Development (Geneva, International Labour Org., pp.1-284).

Obansa, S.A. (2003). "An Assessment of Women Participation in Small Scale Business in Gwagwalada Area Council", Journal of Administration and Management, Abuja, Joyce graphic Pub. Co.

Obansanjo, O. (2006). "No True Democracy Without Women Participation", Nigeria Vanguard, Oct. 28, htpp://www.peacewomen.org/news/Nigera/news.html.

Obasanjo, O. \& A. Mabogunje. (1991). Elements of Development (Lagos: ALF Publication).

ODA, (1995). A Guide to Social Analysis for Projects in Developing Countries, (London HMSO.)

Oguonu, C.N. (2006). “Women and Socio-Economic Development in Local Government System in Nigeria” Women Global Connection Conference Proceeding.

Ojo, M.O. (2003). "Globalisation and Economic Development: International Experiences", the Nigeria Economic Society Globalisation and Africa's Economic Development (Ibadan: Annual Conference, p.73.

Olopoenia, R. A. (1983). "On the Meaning of Development" in Osayimwese I. Z. ed. Development Economies and Planning. (Nigetria: Ibadan, University Press.)

Onokerhoraye, A.G. (1995). The Impact of the Structural Adjustment Programme on Grass-roots Development in Nigeria Benin: the Benin social Science series, p.10.

OsuntogunAdeniyi. (1976). "Rural Women in Agricultural Development: A Nigerian Case Study", Paper presented at the Conference on Nigerian Women and Development in Relation to Changing Family Structure, University of Ibadan, April 26-30. 
Patel and Anthonio, (1973). Patel, A. U and Anthonio, Q. B. O (1973). Farmer's Wives in Agricultural Development: The Nigerian Case: Paper presented at XV International Congress of Agricultural Economists Sao Panlo, Brazil, August 20-29.

Pradip, K. G. (1984). Population, Environment, Resources and Third World Development. (Washingtin D. C.: Greenwood press).

Prakash, D. (2003). Rural Women Food Security and Agricultural Cooperatives: Rural Development and Management, (India, pp1-15).

Riggs, F.W. (1970). "The Context of Development Administration" in Fred Riggs (ed.) Frontiers of Development Administration. Durhan: Duke University Press.

Rodney, W. (1986). How Europe Underdeveloped Africa, (London, Bogle-L'ouverture Publications).

Rostow, W.W. (1960). The Process of Economic Growth, (London: Oxford Univ. Press).

Seer, D. (1981). "The meaning of Development" in Crounch, B. and Chamala, S. Extension education and rural Development, ed. (New-York: John Willey and Sons).

Smock, David F. \& Smock, Andrey C. (1972). Cultural and Political Aspects of Rural Transportation: A case of Eastern Nigeria: London: Praeger Publishers.

Tewe, B. O. (1978). "The Role of women in farm labour supply: A Case Study of Okitipupa Division of Ondo State." Department of Agric. Economics, Uni. of Ibadan.

Todora, M.P. (1992). Economic Development in the Third World (London and New-York: Longman).

United Nations. (1995). United Nations World Summit for Social Development (New-York, United Nations).

UN. (1989). United Nation, Report of the World Food Council, (New-York).

UN. (2000). The World Women: Trends and Statistics (New-York, UN), P111.

UNDP. (1998). Managing Development in Nigeria, (Lagos, UNDP) p.8.

Wiley \& Eskilson, (in Imogie A. O. 2009). "Overcoming Huddles of Stereotypes about Sex and Leadership" in Benin Journal of Gender Studies, Benin Nigeria, Vol. 1, No. 2., p.195. 